\title{
The structure of influence tactics: a cartoon-based measurement system derived from the theater concept of dramatic action
}

Yuvalal Liron, Noa Raindel, Uri Alon

\section{Supplementary Information}

\section{Table of Contents}

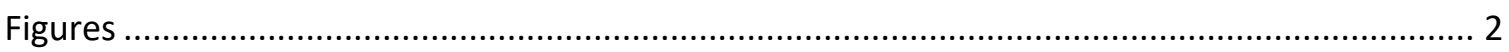

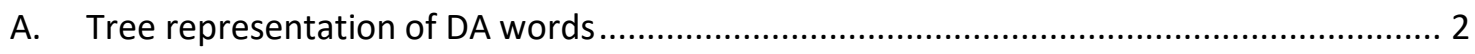

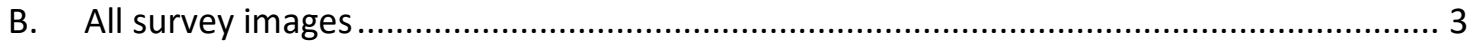

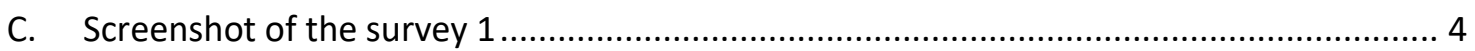

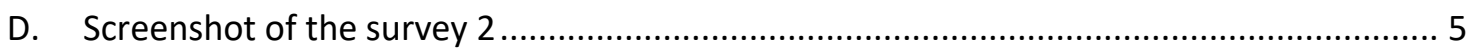

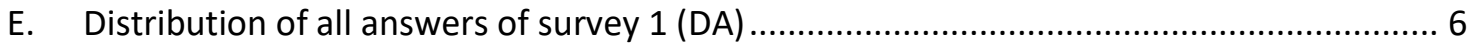

F. Criteria to determine agreement is based on area under the cumulative distribution

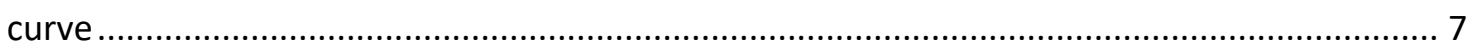

G. Cumulative distribution of all high agreement questions of survey 1 ........................... 8

H. Distribution of all answers of survey 2 (emotions) …................................................ 9

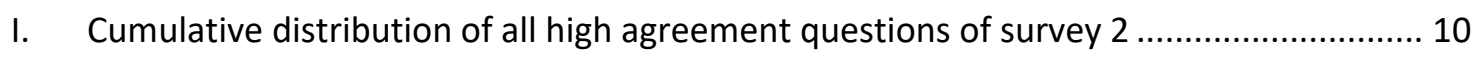

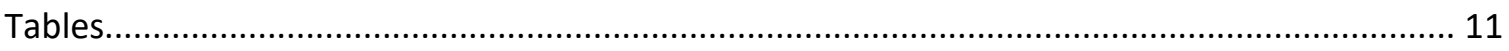

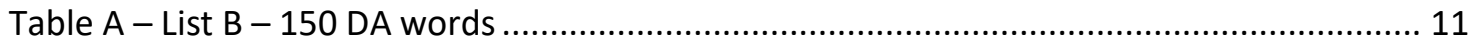

Table B - Analysis of the Specific Affect Coding System (SPAFF) from Ref (1) ........................ 13

Table C - Analysis of the FAU emotion corpus annotations from Ref (3) .............................. 16

Table D - Analysis of ratings used in surgeons' voice-tone rating from Ref (4) ...................... 18

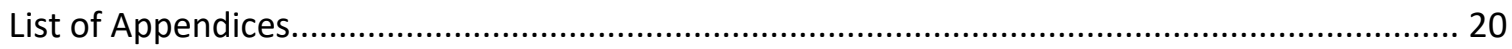

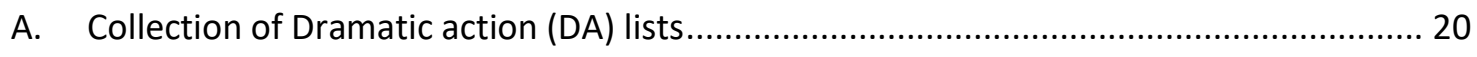

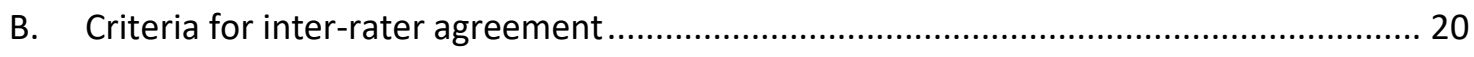

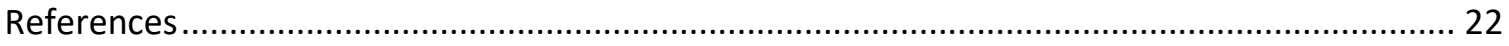




\section{Figures}

\section{A. Tree representation of DA words}

\section{Dramatic actions groups derived from WordNet}

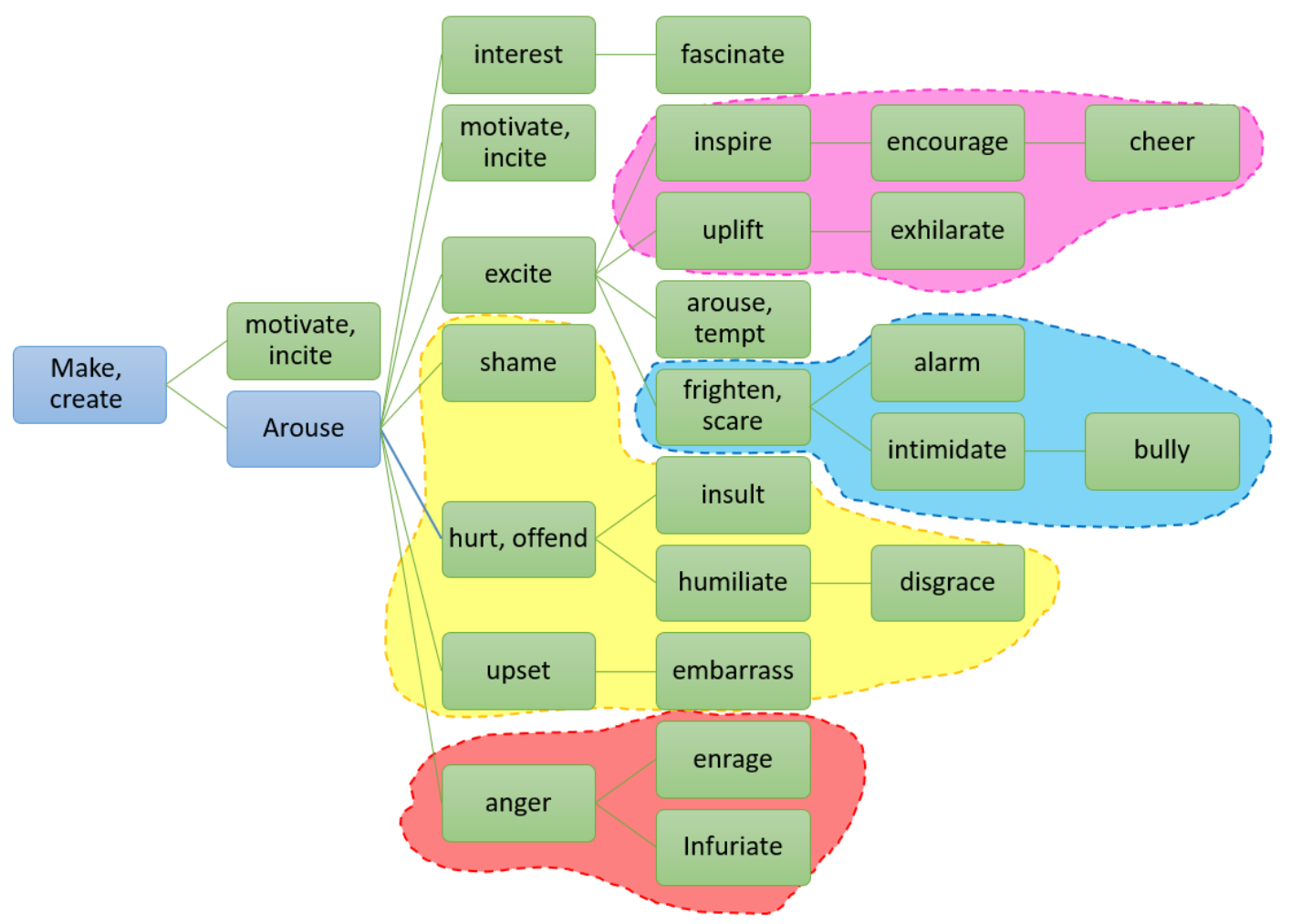

Figure A - Tree representation of DA words. The tree in this diagram is an example of one tree from a graph forest representation of the words in List $B$. The graph hierarchy s based on the WordNet relations of hyponym/hypernym, for example insult and humiliate are hyponyms of hurt. 


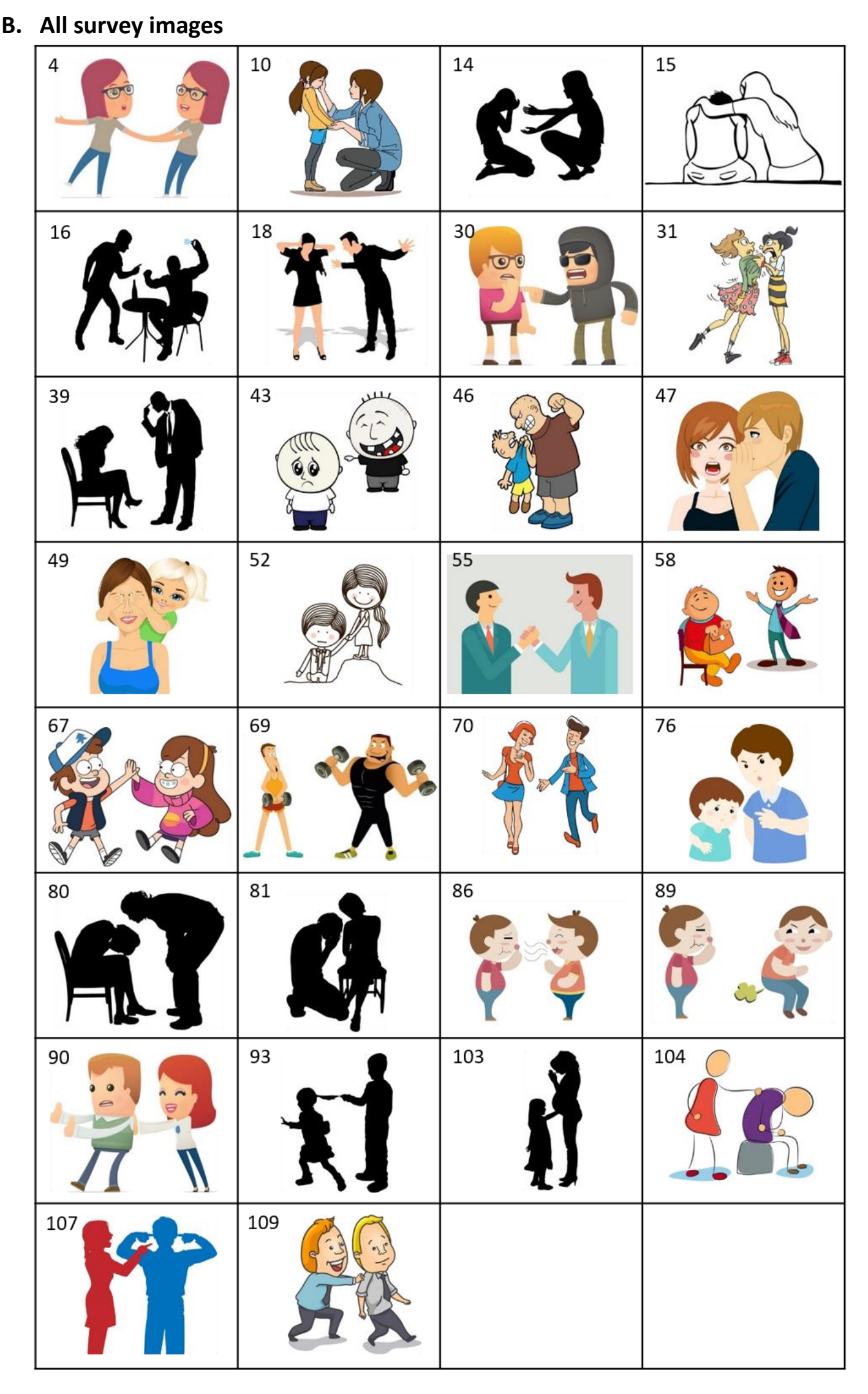


Figure B - All 30 images used for surveys. For survey 2, two variations of each figure were created, with blue arrow above one of the characters in each figure. Figures \#103, \#104 and \#109 were removed from the analysis since the person performing the DA is on the left instead on the right. Cartoons reprinted from Shutterstock.com under a CC BY license, with permission from Shutterstock.

\section{Screenshot of the survey 1}
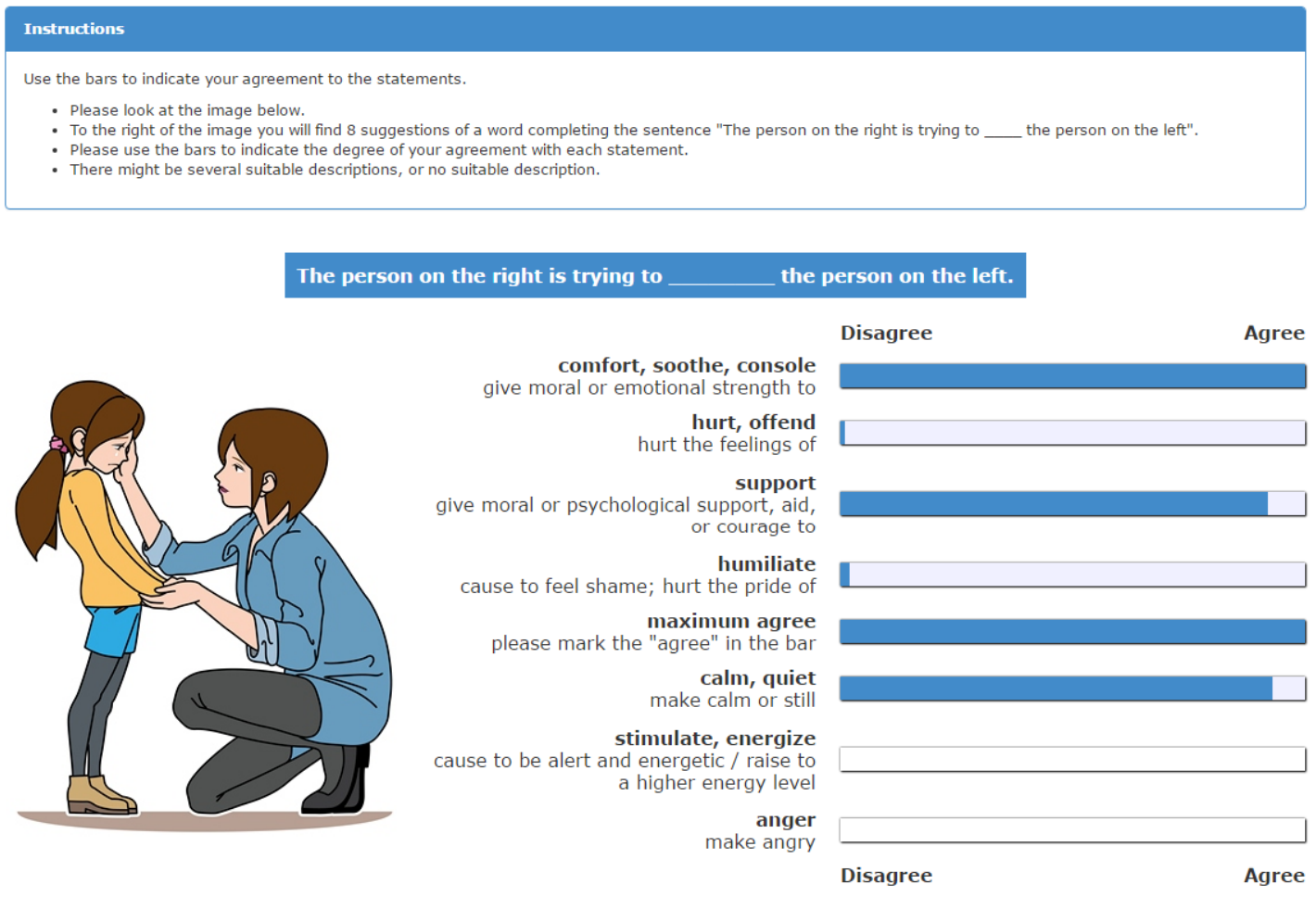

Is there another verb that can complete the sentence and describe the situation in the image? If yes- please write the suitable verb in the box.

Cartoon reprinted from Shutterstock.com under a CC BY license, with permission from Shutterstock.

Figure C - Screenshot of survey 1 (DA words). 


\section{Screenshot of the survey 2}

Instructions
Use the bars to indicate your agreement to the statements.
- Please look at the image below.
To the right of the image you will find 7 suggestions of words completing the sentence "The person on the right is feeling
- Please use the barsed is marked by an arrow.
- There might be several suitable tes degree of your agreement with each statement.

The person on the right is feeling

Disagree

Agree

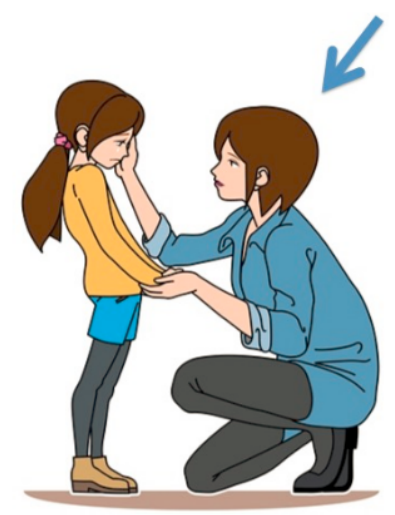

Disgusted minimum agree
please mark the "disagree" in the bar

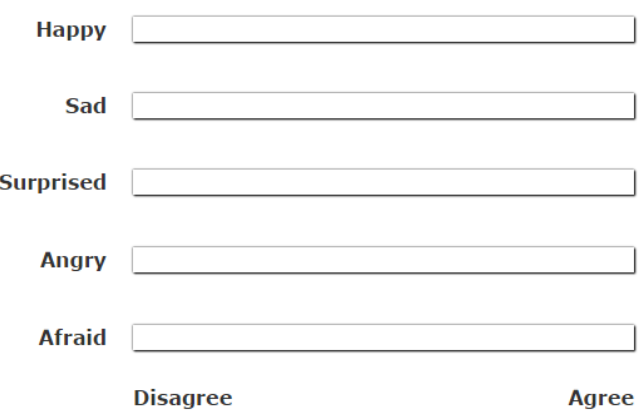

Is there another adjective that can complete the sentence and describe the feelings of the person marked by an arrow? If yes- please write the suitable adjective in the box.

Cartoon reprinted from Shutterstock.com under a CC BY license, with permission from Shutterstock.

Figure D - Screenshot of survey 2 (emotions). 


\section{E. Distribution of all answers of survey 1 (DA)}

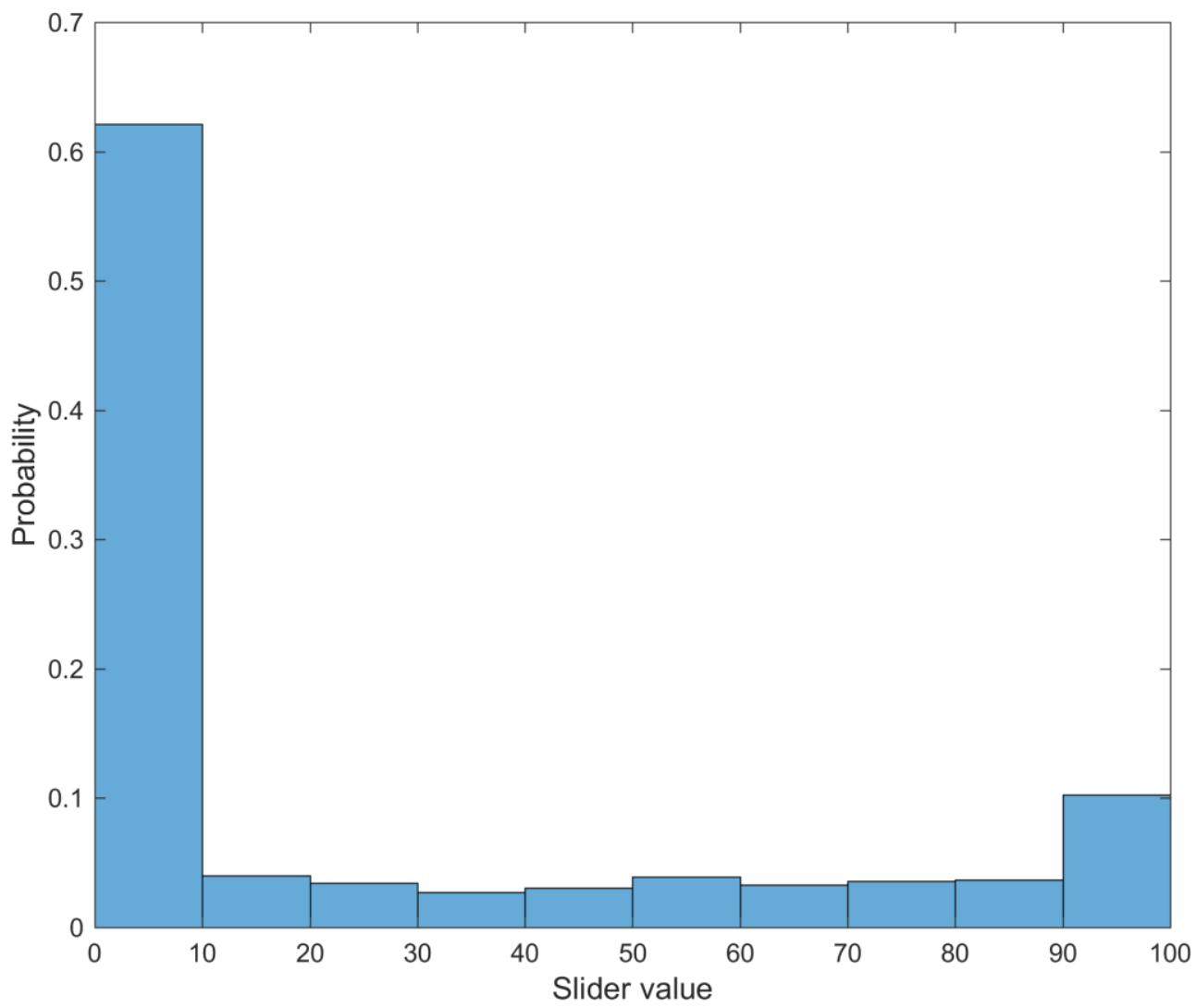

Figure E - Distribution of all answers of survey 1 . The responses to the survey questions tended to be dichotomous. The distribution of all answers in experiment 1 is shown across the different deciles. Majority (62\%) of answers were in the first decile corresponding to strong disagreement with the suggested verb. The distribution is bi-modal with the second peak at the 90-100 decile with about $10 \%$ of the answers. P-value $<10^{-4}$. 


\section{F. Criteria to determine agreement is based on area under the cumulative distribution curve}

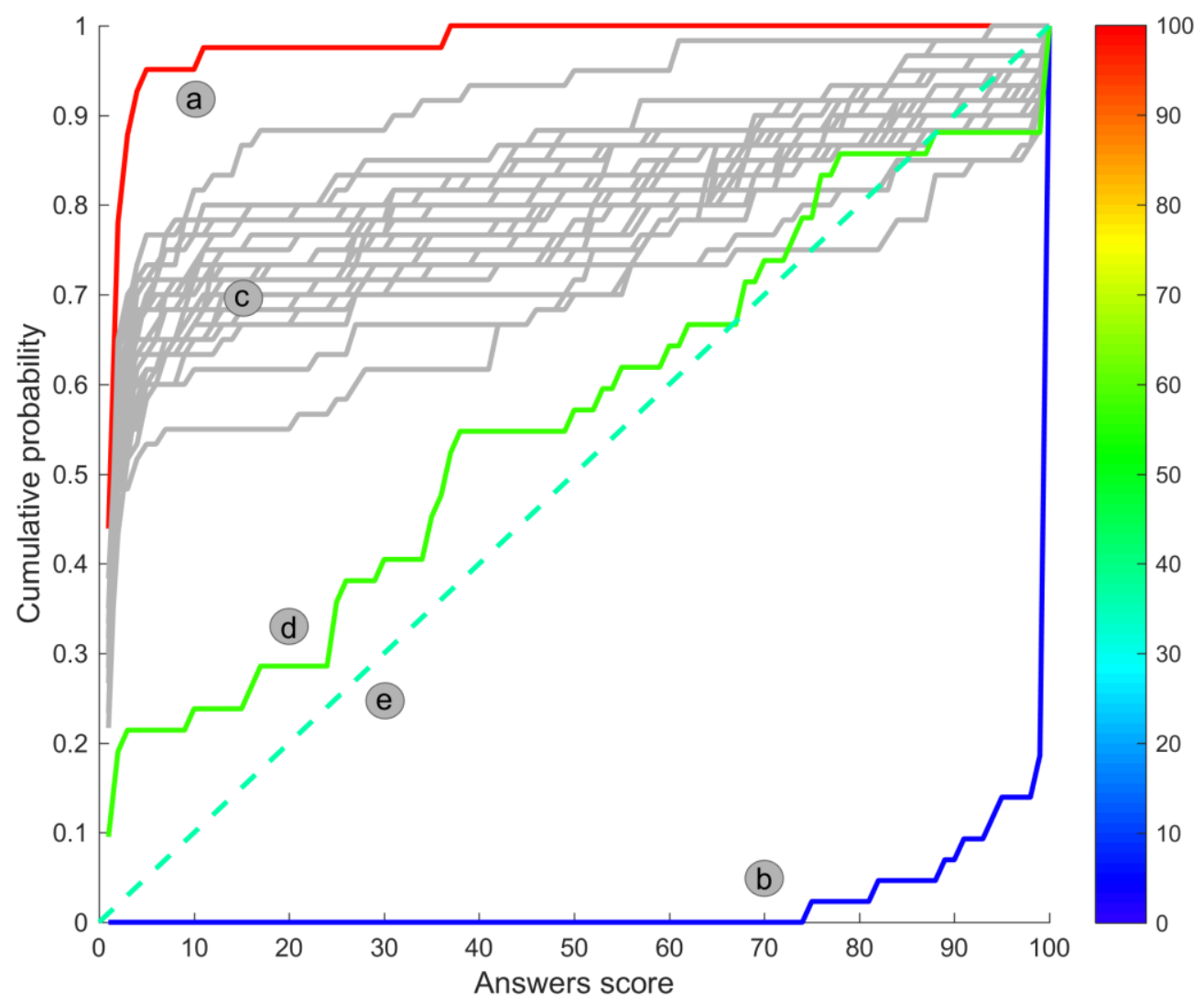

Figure $\mathrm{F}$ - Criteria to determine agreement is based on area under the cumulative distribution curve. Each line represents the empirical cumulative distribution function of answers to one question. The colors represent the area under the cumulative distribution (AUC). (a) Strong agreement on low score. (b) Strong agreement on high score. (c) 25 examples of randomly simulated responses. (d) Weak agreement on high score that is excluded by comparison to uniform distribution (e). 


\section{G. Cumulative distribution of all high agreement questions of survey 1}

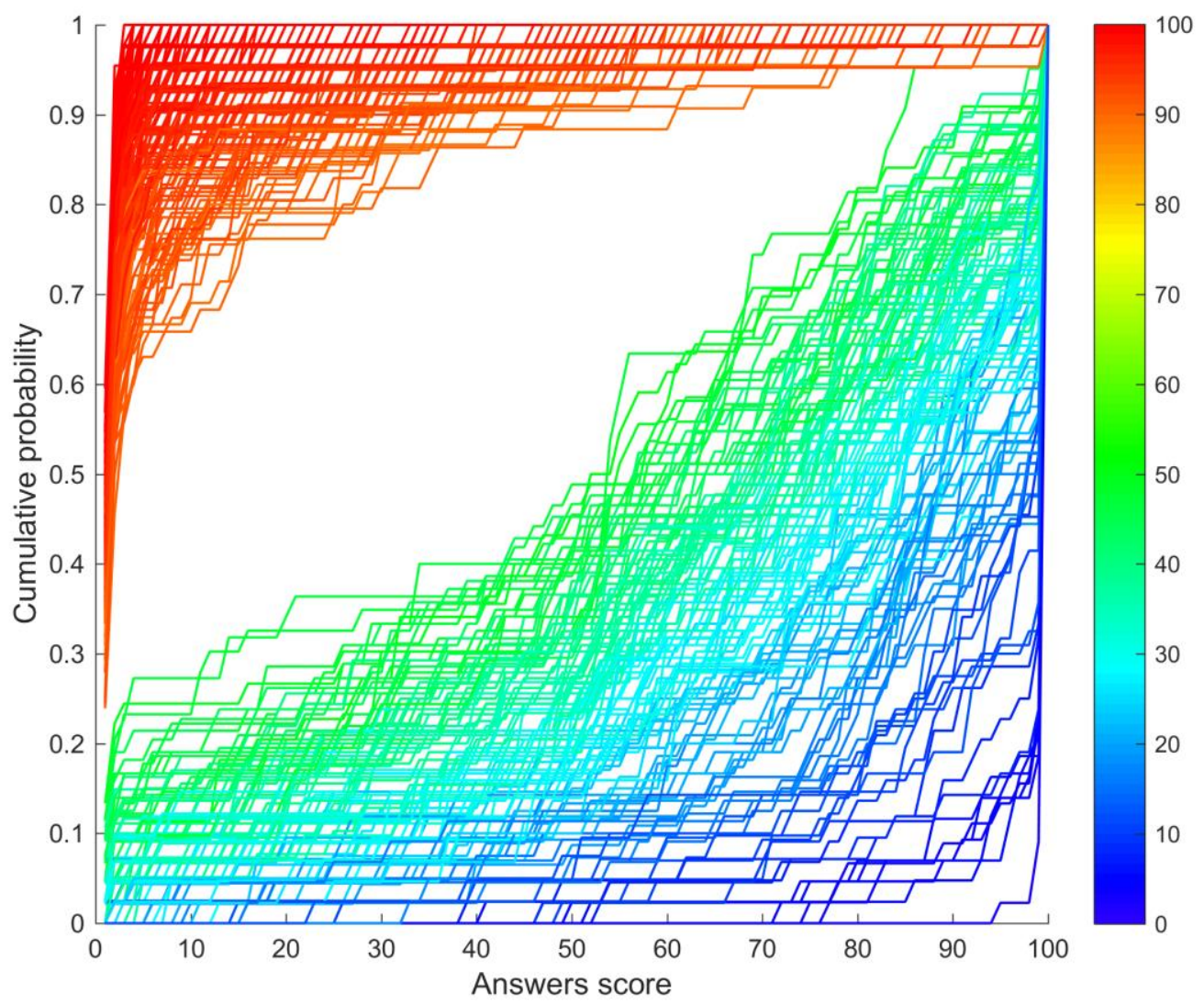

Figure $\mathbf{G}$ - Cumulative distributions of all high-agreement question of survey 1 . The colors represent the area under the cumulative distribution line. The blue-green group of 131 lines is consisted of questions which passed the criteria for "agreement on high score". . The red group of 274 are for questions that passed the criteria for "agreement on low scores". In total, there was significant agreement in $71 \%$ out of 572 questions. 


\section{H. Distribution of all answers of survey 2 (emotions)}

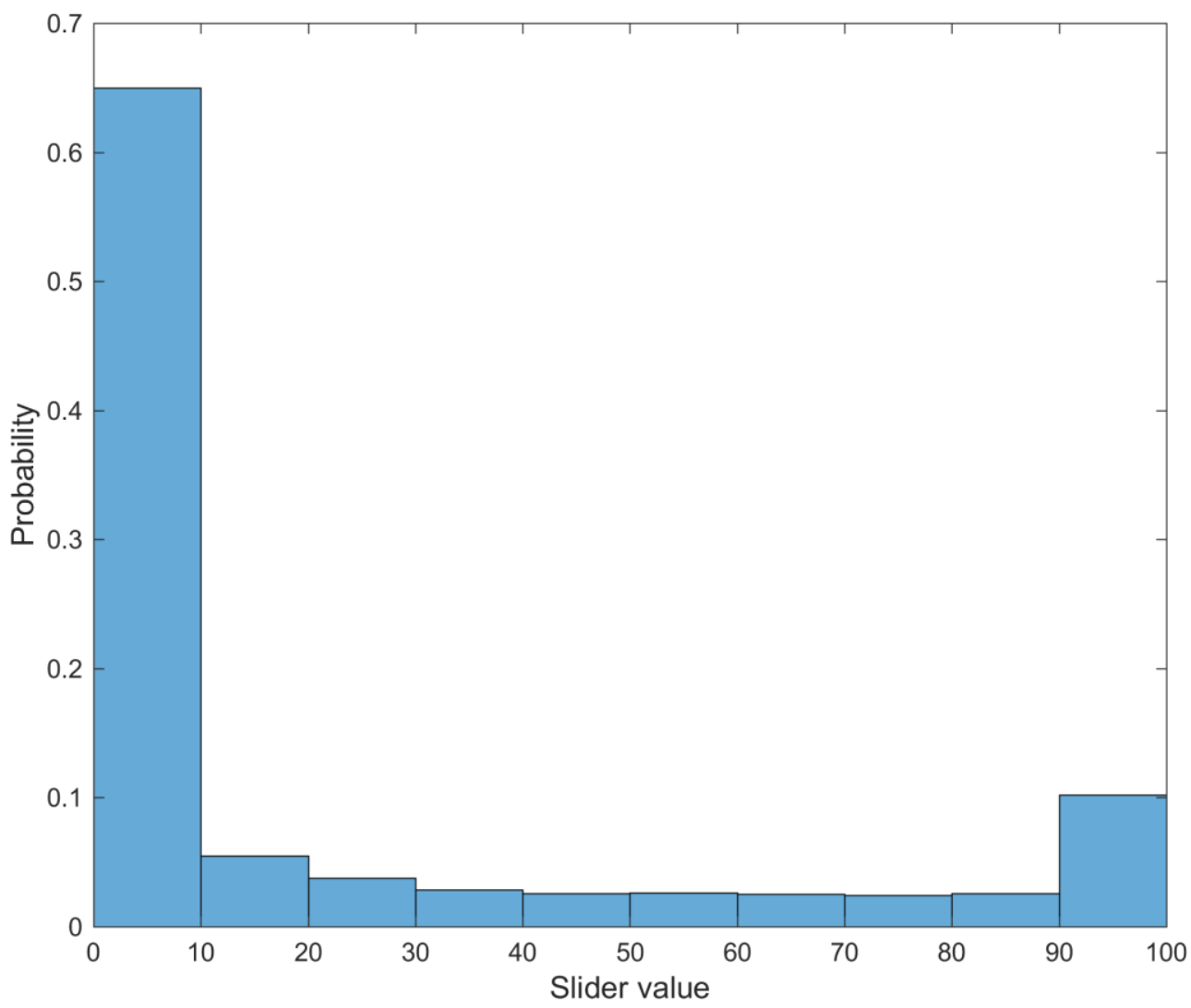

Figure $\mathbf{H}$ - Distribution of all answers of survey 2. The responses to the second survey questions show the same dichotomous distribution as the responses to the first survey. The distribution of all answers in experiment 2 is shown across the different deciles. Majority of answers were in the first decile, about $65 \%$. The distribution is bi-modal with the second peak at the $90-100$ decile with about $10 \%$ of the answers. P-value $<10-4$. 


\section{Cumulative distribution of all high agreement questions of survey 2}

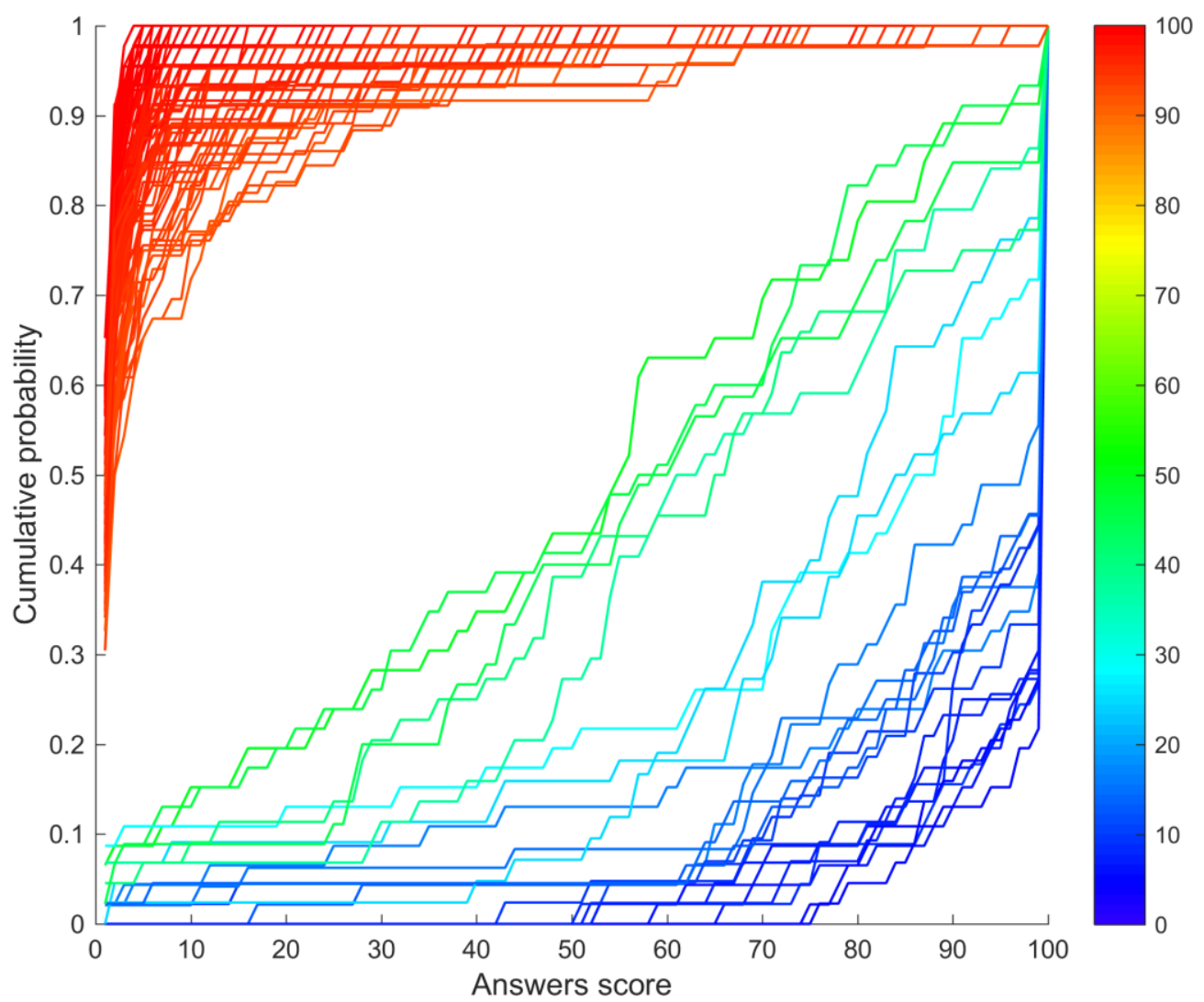

Figure I - Cumulative distributions of all high-agreement questions, asking about the emotion of the character who performs the DA. The colors represent the area under the cumulative distribution line. The blue-green group of 23 lines consists of questions with high-positive agreement. The red group of 85 lines shows the cumulative distribution of questions with highnegative agreement. In total, there was strong agreement in $78 \%$ of 162 questions. 


\section{Tables}

Table A - List B - 150 DA words

\begin{tabular}{|c|c|c|c|c|c|}
\hline support & 1177772 & shame & 35598 & allure & 6903 \\
\hline please & 957803 & exhaust & 35049 & disgust & 6548 \\
\hline hurt & 599098 & tease & 34985 & sicken & 6248 \\
\hline engage & 514981 & pressure & 34375 & invigorate & 6078 \\
\hline encourage & 473843 & delight & 33556 & fright & 5984 \\
\hline bore & 420284 & appease & 32055 & engross & 5464 \\
\hline worry & 410222 & annoy & 31529 & dishonor & 5297 \\
\hline attack & 292508 & alert & 29701 & dishonour & 4703 \\
\hline blame & 283140 & embarrass & 28362 & pester & 4568 \\
\hline attract & 262016 & quiet & 28234 & solace & 4288 \\
\hline capture & 240000 & lure & 27920 & enchant & 3758 \\
\hline strengthen & 211848 & shock & 25286 & affront & 3744 \\
\hline warn & 149528 & seduce & 25170 & sadden & 3375 \\
\hline relax & 144503 & alarm & 25004 & joy & 3361 \\
\hline stimulate & 141912 & intimidate & 24710 & enrage & 3133 \\
\hline entertain & 136524 & entice & 24286 & astound & 2781 \\
\hline inspire & 131848 & recreate & 22000 & swagger & 2748 \\
\hline threaten & 131438 & harass & 21624 & embolden & 2736 \\
\hline dominate & 128239 & scold & 20952 & abase & 2658 \\
\hline impress & 127656 & startle & 20299 & browbeat & 2527 \\
\hline absorb & 119985 & incite & 20139 & appal & 2274 \\
\hline rush & 115484 & irritate & 20116 & hearten & 1944 \\
\hline urge & 114099 & aggravate & 19391 & assault & 1876 \\
\hline excite & 104313 & tire & 18619 & domineer & 1855 \\
\hline ease & 101472 & rebuke & 18438 & affright & 1739 \\
\hline hurry & 97837 & assail & 18306 & entrance & 1706 \\
\hline concern & 97565 & astonish & 17692 & hassle & 1592 \\
\hline comfort & 93205 & caution & 16937 & quieten & 1549 \\
\hline surprise & 82111 & disgrace & 16383 & incense & 1481 \\
\hline provoke & 81963 & pacify & 15529 & transfix & 1426 \\
\hline awaken & 80624 & humiliate & 14860 & appall & 1381 \\
\hline calm & 73811 & waken & 13965 & anger & 1380 \\
\hline amuse & 72503 & befriend & 13576 & revolt & 1294 \\
\hline discourage & 72320 & brace & 12571 & badger & 1253 \\
\hline offend & 71365 & enliven & 12549 & exhilarate & 1139 \\
\hline interest & 69678 & admonish & 12030 & humble & 1054 \\
\hline cheer & 68995 & placate & 11605 & energise & 951 \\
\hline arouse & 64325 & beguile & 11246 & elate & 821 \\
\hline motivate & 63288 & reprove & 11183 & bug & 741 \\
\hline confuse & 62695 & bully & 10755 & abash & 724 \\
\hline frighten & 60100 & amaze & 10439 & tranquillise & 559 \\
\hline rouse & 52601 & hush & 10066 & diss & 538 \\
\hline tempt & 52569 & still & 9932 & trance & 436 \\
\hline distract & 51996 & lull & 9107 & weary & 401 \\
\hline
\end{tabular}




\begin{tabular}{ll|ll|lr} 
scare & 51869 & belittle & 8853 & charm & 366 \\
squeeze & 51644 & fascinate & 8792 & spite & 276 \\
soothe & 48386 & unwind & 8515 & reproof & 241 \\
console & 46132 & energize & 8492 & nettle & 198 \\
mock & 41182 & gladden & 8113 & enamour & 162 \\
repel & 40715 & fatigue & 7624 & bullyrag & 108 \\
insult & 37545 & captivate & 7301 & enamor & 65
\end{tabular}

Table A - List B - 150 DA words

The numbers next to the DA words represent their frequency according to the number of occurrence in the Google NGram database. The words in the list are presented in a descending order of frequencies. 
Table B - Analysis of the Specific Affect Coding System (SPAFF) from Ref (1)

\begin{tabular}{|c|c|c|c|c|c|}
\hline \multirow{2}{*}{$\begin{array}{l}\text { SPAFF code } \\
\text { Gottman et al } \\
2007\end{array}$} & \multirow{2}{*}{$\begin{array}{l}\text { Function (SPAFF } \\
\text { Manual) }\end{array}$} & \multirow[t]{2}{*}{ Goal } & \multicolumn{2}{|l|}{ Tactics } & \multirow[t]{2}{*}{ State } \\
\hline & & & Analysis & $\begin{array}{l}\text { Dramatic } \\
\text { Actions }\end{array}$ & \\
\hline Affection & $\begin{array}{l}\text { Expresses genuine } \\
\text { caring and concern } \\
\text { and offers comfort. }\end{array}$ & & $\begin{array}{l}\text { Elicit positive } \\
\text { emotions } \\
\text { Decrease } \\
\text { sadness, fear } \\
\text { Increase status }\end{array}$ & $\begin{array}{l}\text { To support, } \\
\text { to } \\
\text { encourage, } \\
\text { to comfort, } \\
\text { to soothe, } \\
\text { to calm }\end{array}$ & \\
\hline Anger & $\begin{array}{l}\text { Response to perceived } \\
\text { violations } \\
\text { of the speaker's rights } \\
\text { to autonomy and } \\
\text { respect }\end{array}$ & & & & $\begin{array}{l}\text { Emotion } \\
\text { - Anger }\end{array}$ \\
\hline Belligerence & $\begin{array}{l}\text { To "get a rise" out of } \\
\text { the receiver through } \\
\text { provocation of anger. } \\
\text { The belligerent } \\
\text { speaker is, in a sense, } \\
\text { looking for a fight. }\end{array}$ & & $\begin{array}{l}\text { Elicit anger } \\
\text { Increase } \\
\text { arousal }\end{array}$ & $\begin{array}{l}\text { To anger, to } \\
\text { irritate } \\
\text { As a threat: } \\
\text { to threaten, } \\
\text { to } \\
\text { intimidate }\end{array}$ & \\
\hline Contempt & $\begin{array}{l}\text { To belittle, hurt, or } \\
\text { humiliate. } \\
\text { Communicates an icy } \\
\text { lack of respect, often } \\
\text { cruelty. }\end{array}$ & & $\begin{array}{l}\text { Elicit sadness, } \\
\text { fear } \\
\text { lower other's } \\
\text { status }\end{array}$ & $\begin{array}{l}\text { To belittle, } \\
\text { to hurt, to } \\
\text { humiliate, } \\
\text { to insult, to } \\
\text { bully, to } \\
\text { shame }\end{array}$ & \\
\hline Criticism & $\begin{array}{l}\text { Attack on someone's } \\
\text { character or } \\
\text { personality in a way } \\
\text { that is not obviously } \\
\text { insulting, as in } \\
\text { contempt. } \\
\text { It is often } \\
\text { accompanied by } \\
\text { blame }\end{array}$ & $\begin{array}{l}\text { Change } \\
\text { behavior of } \\
\text { other. It can be } \\
\text { accompanied } \\
\text { by several DAs } \\
\text { that are used as } \\
\text { a tactic to } \\
\text { achieve this } \\
\text { goal. }\end{array}$ & $\begin{array}{l}\text { (i) Elicit guilt } \\
\text { (ii) Elicit fear } \\
\text { (iii) Elicit anger }\end{array}$ & $\begin{array}{l}\text { (i) To scold, } \\
\text { to blame } \\
\text { (ii) To } \\
\text { threaten } \\
\text { (iii) To anger }\end{array}$ & \\
\hline Defensiveness & $\begin{array}{l}\text { Defensiveness } \\
\text { functions to deflect } \\
\text { responsibility or } \\
\text { blame. It } \\
\text { communicates a kind } \\
\text { of innocent } \\
\text { victimhood or } \\
\text { righteous indignation. }\end{array}$ & $\begin{array}{l}\text { Deflect } \\
\text { responsibility. }\end{array}$ & $\begin{array}{l}\text { (i) Decrease } \\
\text { own status } \\
\text { (ii) Increase } \\
\text { own status and } \\
\text { lower other's } \\
\text { (counterattack) }\end{array}$ & $\begin{array}{l}\text { (i) To beg, to } \\
\text { please, to } \\
\text { charm } \\
\text { (ii) To } \\
\text { threaten, to } \\
\text { hurt, to } \\
\text { belittle }\end{array}$ & \\
\hline Disgust & $\begin{array}{l}\text { Involuntary verbal or } \\
\text { nonverbal reaction to } \\
\text { a stimulus that is } \\
\text { perceived to be } \\
\text { noxious }\end{array}$ & & $\begin{array}{l}\text { When includes } \\
\text { active } \\
\text { responses } \\
\text { such as } \\
\text { mockery, } \\
\text { insults or } \\
\text { belittlement it }\end{array}$ & & $\begin{array}{l}\text { Emotion } \\
- \\
\text { Disgust }\end{array}$ \\
\hline
\end{tabular}




\begin{tabular}{|c|c|c|c|c|c|}
\hline & & & $\begin{array}{l}\text { is coded as } \\
\text { contempt. }\end{array}$ & & \\
\hline Domineering & $\begin{array}{l}\text { To exert and } \\
\text { demonstrate } \\
\text { control over one's } \\
\text { partner or a } \\
\text { conversation }\end{array}$ & & $\begin{array}{l}\text { Lower other's } \\
\text { status } \\
\text { Increase own } \\
\text { status }\end{array}$ & $\begin{array}{l}\text { To } \\
\text { dominate, } \\
\text { to belittle, } \\
\text { to threaten, } \\
\text { to bully }\end{array}$ & \\
\hline Enthusiasm & $\begin{array}{l}\text { Express a passionate } \\
\text { interest } \\
\text { in a person or activity } \\
\ldots \\
\text { Enthusiasm is } \\
\text { infectious and often } \\
\text { sudden, loud, } \\
\text { boisterous, and } \\
\text { energetic }\end{array}$ & & $\begin{array}{l}\text { Elicit happiness } \\
\text { Increase } \\
\text { arousal of } \\
\text { both. }\end{array}$ & $\begin{array}{l}\text { To cheer, to } \\
\text { uplift, to } \\
\text { stimulate, to } \\
\text { energize }\end{array}$ & \\
\hline Fear/Tension & $\begin{array}{l}\text { Communicates, } \\
\text { usually involuntarily, } \\
\text { fear, worry, anxiety, } \\
\text { nervous anticipation, } \\
\text { or dread. }\end{array}$ & & & & $\begin{array}{l}\text { Emotion } \\
\text { - Fear }\end{array}$ \\
\hline Humor & $\begin{array}{l}\text { To share in mutual } \\
\text { amusement and joy } \\
\text { following a mutually } \\
\text { recognized moment of } \\
\text { absurdity or fun. }\end{array}$ & & $\begin{array}{l}\text { Elicit } \\
\text { happiness, } \\
\text { amusement } \\
\text { Increase } \\
\text { other's arousal } \\
\text { Increase } \\
\text { togetherness }\end{array}$ & $\begin{array}{l}\text { To amuse, } \\
\text { to uplift }\end{array}$ & \\
\hline Interest & $\begin{array}{l}\text { To communicate } \\
\text { genuine interest in } \\
\text { one's partner through } \\
\text { active elaboration or } \\
\text { clarification seeking }\end{array}$ & $\begin{array}{l}\text { Collect } \\
\text { information and } \\
\text { create good } \\
\text { communication. }\end{array}$ & $\begin{array}{l}\text { Elicit positive } \\
\text { emotion } \\
\text { Increase } \\
\text { other's status }\end{array}$ & $\begin{array}{l}\text { To } \\
\text { empower, } \\
\text { to } \\
\text { encourage }\end{array}$ & \\
\hline Sadness & $\begin{array}{l}\text { Behaviors that } \\
\text { communicate loss, } \\
\text { resignation, } \\
\text { helplessness, } \\
\text { pessimism, } \\
\text { hopelessness, or a } \\
\text { plaintive or poignant } \\
\text { quiescence. }\end{array}$ & & & & $\begin{array}{l}\text { Emotion } \\
- \\
\text { Sadness }\end{array}$ \\
\hline Stonewalling & $\begin{array}{l}\text { Communicate an } \\
\text { unwillingness to listen } \\
\text { or respond to the } \\
\text { receiver. } \\
\text { Communicating the } \\
\text { message, "I'd rather } \\
\text { not be here right now, } \\
\text { and I don't want to } \\
\text { listen to you." }\end{array}$ & & $\begin{array}{l}\text { Elicit negative } \\
\text { emotion. } \\
\text { Lower other's } \\
\text { status } \\
\text { Raise other's } \\
\text { arousal }\end{array}$ & $\begin{array}{l}\text { To anger, to } \\
\text { belittle, to } \\
\text { humiliate }\end{array}$ & \\
\hline
\end{tabular}




\begin{tabular}{|c|c|c|c|c|}
\hline Threats & $\begin{array}{l}\text { Particularly hostile } \\
\text { form of domineering } \\
\text { behavior in that their } \\
\text { function is to control } \\
\text { the behavior of the } \\
\text { receiver by setting } \\
\text { explicit conditions } \\
\text { under which the } \\
\text { receiver will be } \\
\text { punished for behaving } \\
\text { in ways the speaker } \\
\text { finds undesirable. }\end{array}$ & $\begin{array}{l}\text { Change } \\
\text { behavior of } \\
\text { other }\end{array}$ & $\begin{array}{l}\text { Can be } \\
\text { accompanied } \\
\text { by various DAs }\end{array}$ & $\begin{array}{l}\text { E.g. to } \\
\text { threat, to } \\
\text { hurt, to } \\
\text { belittle, to } \\
\text { impress }\end{array}$ \\
\hline Validation & $\begin{array}{l}\text { Communicate sincere } \\
\text { understanding and } \\
\text { acceptance of one's } \\
\text { partner or of } \\
\text { one's partner's views } \\
\text { and opinions }\end{array}$ & & $\begin{array}{l}\text { Elicit positive } \\
\text { emotion } \\
\text { Increase } \\
\text { other's status }\end{array}$ & $\begin{array}{l}\text { To support, } \\
\text { to } \\
\text { encourage }\end{array}$ \\
\hline Whining & $\begin{array}{l}\text { Make what might } \\
\text { otherwise be an } \\
\text { ordinary complaint } \\
\text { into a plaintive or } \\
\text { pleading form of } \\
\text { emotional protest. } \\
\text { Whining suggests an } \\
\text { innocent victim stance }\end{array}$ & & $\begin{array}{l}\text { Decrease own } \\
\text { status } \\
\text { Can be } \\
\text { accompanied } \\
\text { by various DAs }\end{array}$ & $\begin{array}{l}\text { E.g. to } \\
\text { pressure, to } \\
\text { blame, to } \\
\text { urge }\end{array}$ \\
\hline
\end{tabular}

\section{Table B: Analysis of the Specific Affect Coding System (SPAFF) from Ref (1).}

The Specific Affect Coding System (SPAFF) was introduced by Gottman and Krokoff(2) in 1989 for the purpose of systematically observing affective behavior in the context of marital conflict. The SPAFF has been widely used in scientific research, and was refined over the years. This analysis, done by the authors, is based on the complete description of the SPAFF, including its history and coding manual, published in Ref (1). 
Table C - Analysis of the FAU emotion corpus annotations from Ref (3)

\begin{tabular}{|c|c|c|c|c|c|}
\hline \multirow{2}{*}{$\begin{array}{l}\text { FAU-AIBO } \\
\text { annotation } \\
\text { Batliner et al } \\
2004\end{array}$} & \multirow[t]{2}{*}{ Description } & \multirow[t]{2}{*}{ Goal } & \multicolumn{2}{|c|}{ Dramatic action (tactics) } & \multirow[t]{2}{*}{ State } \\
\hline & & & Analysis & Actions & \\
\hline Joyful & $\begin{array}{l}\text { The child enjoys AIBO's } \\
\text { action and/or notices } \\
\text { that something is } \\
\text { funny. }\end{array}$ & & & & $\begin{array}{l}\text { Emotion - } \\
\text { happy }\end{array}$ \\
\hline Surprised & $\begin{array}{l}\text { The child is (positively) } \\
\text { surprised because } \\
\text { obviously, he/she did } \\
\text { not expect AIBO to } \\
\text { react that way. }\end{array}$ & & & & $\begin{array}{l}\text { Emotion - } \\
\text { positive } \\
\text { surprise }\end{array}$ \\
\hline Motherese & $\begin{array}{l}\text { The child addressed } \\
\text { AIBO in the way } \\
\text { mothers/parents } \\
\text { address their babies } \\
\text { (also called 'infant- } \\
\text { directed speech')- } \\
\text { either because } \\
\text { AIBO is well-behaving } \\
\text { or because the child } \\
\text { wants } \\
\text { AlBO to obey; this is } \\
\text { the positive equivalent } \\
\text { to reprimanding. }\end{array}$ & $\begin{array}{l}\text { Wants AIBO } \\
\text { to OBEY- } \\
\text { preserve or } \\
\text { improve }\end{array}$ & $\begin{array}{l}\text { Elicit } \\
\text { positive } \\
\text { emotion } \\
\text { Increase } \\
\text { other's } \\
\text { arousal }\end{array}$ & $\begin{array}{l}\text { To encourage, } \\
\text { to soothe }\end{array}$ & \\
\hline Bored & $\begin{array}{l}\text { The child is } \\
\text { (momentarily) not } \\
\text { interested in the } \\
\text { interaction with AIBO. }\end{array}$ & & & & $\begin{array}{l}\text { State }- \text { low } \\
\text { arousal } \\
\text { Can be } \\
\text { related to } \\
\text { sadness. }\end{array}$ \\
\hline Emphatic & $\begin{array}{l}\text { The child speaks in a } \\
\text { pronounced, } \\
\text { accentuated, } \\
\text { sometimes hyper- } \\
\text { articulated way but } \\
\text { without 'showing any } \\
\text { emotion'. }\end{array}$ & & $\begin{array}{l}\text { Increase } \\
\text { other's } \\
\text { arousal* }\end{array}$ & $\begin{array}{l}\text { To urge, to } \\
\text { rush }\end{array}$ & \\
\hline Helpless & $\begin{array}{l}\text { The child is hesitant, } \\
\text { seems not to know } \\
\text { what to tell AIBO next; } \\
\text { can be marked by } \\
\text { disfluencies and/or } \\
\text { filled pauses. }\end{array}$ & & & & $\begin{array}{l}\text { State - } \\
\text { anxiety }\end{array}$ \\
\hline $\begin{array}{l}\text { Touchy } \\
\text { (irritated) }\end{array}$ & $\begin{array}{l}\text { The child is slightly } \\
\text { irritated; this is a pre- } \\
\text { stage of anger. }\end{array}$ & & & & $\begin{array}{l}\text { State - low } \\
\text { intense } \\
\text { anger }\end{array}$ \\
\hline Reprimanding & $\begin{array}{l}\text { The child is } \\
\text { reproachful, } \\
\text { reprimanding, 'wags } \\
\text { the finger'; this is the }\end{array}$ & $\begin{array}{l}\text { Wants AIBO } \\
\text { to OBEY- } \\
\text { improve }\end{array}$ & $\begin{array}{l}\text { Elicit } \\
\text { negative } \\
\text { emotion }\end{array}$ & $\begin{array}{l}\text { To criticize, to } \\
\text { scold }\end{array}$ & \\
\hline
\end{tabular}




\begin{tabular}{|l|l|l|l|l|l|}
\hline & $\begin{array}{l}\text { negative equivalent to } \\
\text { motherese. }\end{array}$ & $\begin{array}{l}\text { Increase } \\
\text { other's } \\
\text { arousal }\end{array}$ & & \\
\hline Angry & $\begin{array}{l}\text { The child is clearly } \\
\text { angry, annoyed, } \\
\text { speaks in a loud voice. }\end{array}$ & & $\begin{array}{l}\text { emotion - } \\
\text { anger }\end{array}$ \\
\hline
\end{tabular}

Table C: Analysis of the FAU emotion corpus annotations from Ref (3)

The FAU AIBO Emotion Corpus was created in order to develop and assess emotion recognition algorithms. It is based on recordings of children instructing a robotic dog to fulfil specific tasks.

*: based on authors' analysis of the recordings kindly provided by Steidl et al. 
Table D - Analysis of ratings used in surgeons' voice-tone rating from Ref (4)

\begin{tabular}{|c|c|c|c|c|c|}
\hline \multirow{2}{*}{$\begin{array}{l}\text { Voice ratings } \\
\text { Ambady et al } 2002\end{array}$} & \multirow{2}{*}{$\begin{array}{l}\text { Definition } \\
\text { (WordNet) }\end{array}$} & \multirow[t]{2}{*}{ Goal } & \multicolumn{2}{|c|}{ Dramatic action (tactics) } & \multirow[t]{2}{*}{ State } \\
\hline & & & Analysis & Actions & \\
\hline Warm & $\begin{array}{l}\text { Friendly and } \\
\text { responsive }\end{array}$ & $\begin{array}{l}\text { Make the } \\
\text { patient feel } \\
\text { comfortable }\end{array}$ & $\begin{array}{l}\text { Elicit positive } \\
\text { emotion }\end{array}$ & $\begin{array}{l}\text { To } \\
\text { encourage, } \\
\text { to support }\end{array}$ & \\
\hline Anxious/concerned & $\begin{array}{l}\text { Feeling or } \\
\text { showing worry } \\
\text { or solicitude }\end{array}$ & $\begin{array}{l}\text { Show concern } \\
\text { for the patient }\end{array}$ & $\begin{array}{l}\text { Elicit positive } \\
\text { emotion }\end{array}$ & $\begin{array}{l}\text { To support, } \\
\text { to soothe }\end{array}$ & \\
\hline Interested & $\begin{array}{l}\text { Having or } \\
\text { showing } \\
\text { interest }\end{array}$ & $\begin{array}{l}\text { Collect } \\
\text { information and } \\
\text { create good } \\
\text { communication. }\end{array}$ & $\begin{array}{l}\text { Elicit positive } \\
\text { emotion } \\
\text { Increase } \\
\text { other's } \\
\text { status }\end{array}$ & $\begin{array}{l}\text { To } \\
\text { empower, } \\
\text { to } \\
\text { encourage }\end{array}$ & \\
\hline Hostile & $\begin{array}{l}\text { Characterized } \\
\text { by enmity or ill } \\
\text { will }\end{array}$ & & $\begin{array}{l}\text { Elicit fear, } \\
\text { sadness }\end{array}$ & $\begin{array}{l}\text { To hurt, to } \\
\text { offend, to } \\
\text { humiliate, } \\
\text { to upset }\end{array}$ & \\
\hline Sympathetic & $\begin{array}{l}\text { Expressing or } \\
\text { feeling or } \\
\text { resulting from } \\
\text { sympathy or } \\
\text { compassion or } \\
\text { friendly fellow } \\
\text { feeling }\end{array}$ & $\begin{array}{l}\text { Make the } \\
\text { patient feel a } \\
\text { friendly } \\
\text { environment }\end{array}$ & $\begin{array}{l}\text { Elicit positive } \\
\text { emotion } \\
\text { Lower } \\
\text { arousal }\end{array}$ & $\begin{array}{l}\text { To comfort, } \\
\text { to soothe, } \\
\text { to console, } \\
\text { to calm, to } \\
\text { quiet }\end{array}$ & \\
\hline Professional & $\begin{array}{l}\text { Characteristic } \\
\text { of or befitting } \\
\text { a profession }\end{array}$ & $\begin{array}{l}\text { Open to } \\
\text { interpretation. } \\
\text { E.g. } \\
\text { - Make the } \\
\text { patient feel } \\
\text { secure } \\
\text { - Keep the } \\
\text { interaction } \\
\text { not } \\
\text { personal }\end{array}$ & $\begin{array}{l}\text { (i) Increase } \\
\text { security } \\
\text { Increase own } \\
\text { status } \\
\text { (ii) Decrease } \\
\text { relationship }\end{array}$ & $\begin{array}{l}\text { (i) To } \\
\text { impress, to } \\
\text { calm } \\
\text { (ii) To } \\
\text { distance* }\end{array}$ & \\
\hline Competent & $\begin{array}{l}\text { Properly or } \\
\text { sufficiently } \\
\text { qualified or } \\
\text { capable or } \\
\text { efficient }\end{array}$ & $\begin{array}{l}\text { Make the } \\
\text { patient feel } \\
\text { secure }\end{array}$ & $\begin{array}{l}\text { Increase } \\
\text { security } \\
\text { Increase own } \\
\text { status }\end{array}$ & $\begin{array}{l}\text { To impress, } \\
\text { to calm }\end{array}$ & \\
\hline Dominant & $\begin{array}{l}\text { Exercising } \\
\text { influence or } \\
\text { control }\end{array}$ & $\begin{array}{l}\text { Control the } \\
\text { interaction }\end{array}$ & $\begin{array}{l}\text { Lowers } \\
\text { other's } \\
\text { status } \\
\text { Increase own } \\
\text { status }\end{array}$ & $\begin{array}{l}\text { To } \\
\text { dominate, } \\
\text { to belittle, } \\
\text { to threaten, } \\
\text { to bully } \\
\text { To impress }\end{array}$ & \\
\hline Satisfied & $\begin{array}{l}\text { Filled with } \\
\text { satisfaction }\end{array}$ & & & & $\begin{array}{l}\text { State - } \\
\text { satisfaction }\end{array}$ \\
\hline Genuine & $\begin{array}{l}\text { Not } \\
\text { pretended; }\end{array}$ & & & & \\
\hline
\end{tabular}




\begin{tabular}{|l|l|l|l|l|l|}
\hline & $\begin{array}{l}\text { sincerely felt } \\
\text { or expressed }\end{array}$ & & & & \\
\hline
\end{tabular}

Table D: Analysis of ratings used in surgeons' voice-tone rating from Ref (4)

In this study of doctor-patient interaction, surgeons were audiotaped while speaking to their patients during office visits. Very brief samples (10-seconds) of the conversations were rated by coders. As the raters were not given any further training or any feedback, we use here the WordNet definition for the voice ratings, choosing the definition most appropriate for the doctor-patient context.

*To distance may not be the best verb to describe this DA, as it can also be perceived as a goal (i.e. make the interaction less personal). As a DA, we refer to an action done by the doctor in order to deflate a patient's attempt to bring the interaction to an emotional or personal level. This could be regarded as a version of Gottman's stonewalling. 


\section{List of Appendices}

\section{A. Collection of Dramatic action (DA) lists}

In order to narrow down list A of 3602 transitive verbs to a concise list of DAs, we used previous lists of DA words from various non-scientific sources on the web. The main lists are available on our website here: link

\section{B. Criteria for inter-rater agreement}

To compute agreement for each question (image-DA combination), one cannot use Krippendorff's alpha because it requires comparison between at least two questions (8). We therefore used a statistical test that picked up on the fact that, for the vast majority of questions, most respondents agreed on either high or low scores. The challenge was that the responses had a noisy structure: often a sizable minority of the respondents had a wide range of responses. To address this noise, we used a statistical test based on bootstrapping (9). For each question, we listed the respondents that answered $(\mathrm{N}=39-47$ in the dataset filtered using the attention checks). We generated $\mathrm{N}$ shuffled responses, by choosing for each respondent a response score taken at random from the set of all responses of that responder in the survey, thus keeping the statistics of each respondent the same. We aimed to score as "agreement on high score" a situation where the majority of responders agree on very high scores. We could not use median or mean score because the noise in the responses could show a relatively high median or mean but with a flat distribution of answers. We therefore evaluated the cumulative distribution of responses for the shuffled data, and computed the area under this cumulative distribution, denoted AUC (area under the curve). The AUC is 0 if all respondents answered the maximal score (100), and is 1 if all respondents answered 0 , and is a sensitive discriminator against uniform distributions of scores $(A \cup C=0.5)$. We repeated the shuffling $10^{4}$ times for each question, and thus generated an ensemble of $10^{4}$ shuffled AUCs for each question. We scored a question as "agreement on high score" if the AUC of the real data was in the lowest $(5 / M) \%=0.0023 \%$ of the shuffled data, where $M=22$ is the number of words tested for that image (Figure F-a). Dividing by $\mathrm{M}$ is a Bonferroni correction for multiple hypothesis testing for each image. Similarly, we scored a question as "agreement on low score" if the AUC of the real data was in the highest $(5 / M) \%$ of the shuffled data (Figure F-b). Figure F-c shows a subset of the 10000 shuffled datasets used to determine significance. 
Our data was generally skewed towards low scores (See SI Figure G). As a result, questions such as depicted in Figure F-d are scored as "agreement on high-score" with a significantly low pvalue, despite the fact that the majority of responders to this question scored low (more than $50 \%$ of responders gave score $<50$ ). In order to filter out such cases (which amount to about $7 \%$ of the questions), we added an additional criterion for "agreement on high-score", namely that the AUC is smaller than the AUC of a uniform distribution of scores (i.e. AUC $<0.5$ for positive agreement). 


\section{References}

1. Coan JA, Gottman JM (2007) The Specific Affect Coding System (SPAFF). Handbook of Emotion Elicitation and Assessment, eds Coan JA, Allen JJB (Oxford University Press), pp 267-285. 1st editio.

2. Gottman JM, Krokoff LJ (1989) Marital interaction and satisfaction: A longitudinal view. J Consult Clin Psychol 57(1):47-52.

3. Batliner A, Steidl S, Hacker C, Nöth E (2008) Private emotions versus social interaction: a data-driven approach towards analysing emotion in speech. User Model User-adapt Interact 18(1-2):175-206.

4. Ambady N, et al. (2002) Surgeons' tone of voice: A clue to malpractice history. Surgery 132(1):5-9.

5. Park S (2013) Persuasiveness in social multimedia. Proceedings of the 15th ACM on International Conference on Multimodal Interaction - ICMI '13 (ACM Press, New York, New York, USA), pp 321-324.

6. Tosti-Kharas J, Conley C (2016) Coding Psychological Constructs in Text Using Mechanical Turk: A Reliable, Accurate, and Efficient Alternative. Front Psychol 7:741.

7. Cocos A, Masino A, Qian T, Pavlick E, Callison-Burch C (2015) Effectively Crowdsourcing Radiology Report Annotations. Proceedings of the Sixth International Workshop on Health Text Mining and Information Analysis (Association for Computational Linguistics, Stroudsburg, PA, USA), pp 109-114.

8. Krippendorff K Content Analysis: An Introduction to Its Methodology (SAGE Publications, Inc). 3rd Ed.

9. Efron B, Tibshirani RJ An Introduction to the Bootstrap (Chapman and Hall/CRC). 1st Ed. 